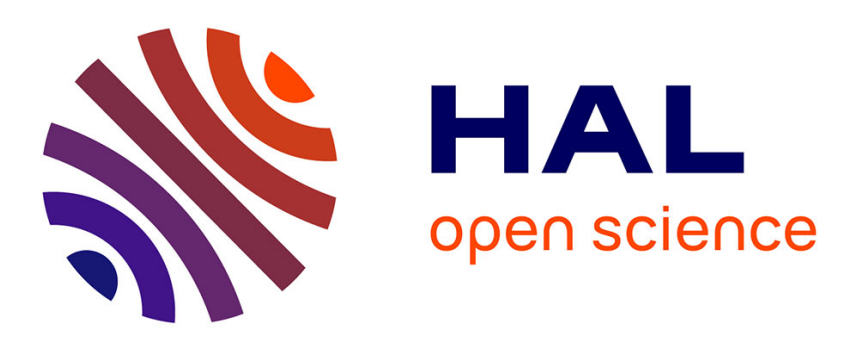

\title{
Adherence and chemoprevention in major cardiovascular disease: A simulation study of the benefits of additional use of statins.
}

\author{
Amir Shroufi, John Powles
}

\section{- To cite this version:}

Amir Shroufi, John Powles. Adherence and chemoprevention in major cardiovascular disease: A simulation study of the benefits of additional use of statins.. Journal of Epidemiology and Community Health, 2010, 64 (2), pp.109-n/a. 10.1136/jech.2009.091033 . hal-00499244

\section{HAL Id: hal-00499244 \\ https://hal.science/hal-00499244}

Submitted on 9 Jul 2010

HAL is a multi-disciplinary open access archive for the deposit and dissemination of scientific research documents, whether they are published or not. The documents may come from teaching and research institutions in France or abroad, or from public or private research centers.
L'archive ouverte pluridisciplinaire HAL, est destinée au dépôt et à la diffusion de documents scientifiques de niveau recherche, publiés ou non, émanant des établissements d'enseignement et de recherche français ou étrangers, des laboratoires publics ou privés. 
Adherence and chemoprevention in major cardiovascular disease: A simulation study of the benefits of additional use of statins.

Shroufi A ${ }^{1}$, Powles JW ${ }^{2}$.

1 NHS Mid Essex, Chelmsford, Essex, UK.

2 Institute of Public Health, , Cambridge, UK.

Correspondence: Amir Shroufi, NHS Mid Essex, Swift House, Chelmsford, Essex, CM2 5PF, UK. E-mail: amir.shroufi@ doctors.org.uk.

Tel-1: 01245 398732. Tel-2: 07771965945 Fax: 01245398711 


\begin{abstract}
Background

In everyday practice, adherence with preventive medications for cardiovascular disease (CVD) is lower than in clinical trials and appears to decline to around $50 \%$ by around 5 years.

The UK body for the evaluation of health technologies, NICE, currently recommends that persons with a greater than $20 \% 10$ year risk of incident cardiovascular disease receive statins.
\end{abstract}

\title{
Methods
}

Publications on adherence with statin medication in clinical trials and in normal practice were systematically reviewed.

We used data on CVD-free members of a large Southern Hemisphere cohort study to simulate the expected benefits of contrasting strategies to increase the use of statins.

Risks of incident CVD and CVD death were estimated using the equations of Anderson et al.

\section{Results}

A strategy to enhance statin adherence among cohort members meeting NICE statin prescribing guidelines resulted in about twice as large a reduction in the aggregate risk of CVD death as did a strategy to lower treatment thresholds.

\section{Conclusions}

The benefits from increased spend on statin medication will be much greater if it results from enhanced adherence rather than from a lowering of the medication threshold. 


\section{Introduction}

The 3-hydroxy-3-methylglutarate coenzyme A reductase inhibitors (statins) are the only class of drug widely used for the purpose of cholesterol lowering. A recent metaanalysis of 164 placebo controlled trials suggested that statin use was associated with an average reduction of LDL cholesterol concentration of around 1.8mmol/1.

Reductions in the incidence of IHD and stroke were estimated to be as high as $60 \%$ and $17 \%$ respectively. [1] Such gains are unlikely to be achieved in treated populations however because sustained adherence with statins in the community is generally low. [2-8]

In principle there are 2 ways of extending the population benefits from increased statin use; one is to lower the treatment threshold, the other is to enhance adherence among those already eligible for treatment. Although means of increasing adherence over the long term are not reliably known, it remains of interest to estimate the potential benefits.

In the UK the National Institute for Clinical Excellence (NICE) now recommends that those with a $20 \%$ or greater 10 year risk of incident cardiovascular disease (CVD) receive statins. [9] Only the adherent among the eligible will gain substantial benefit, yet the non-adherent are likely to be at greater risk.

Discussion hitherto has focussed on increasing the population benefits of statins by lowering the thresholds for treatment. Here we consider, as an alternative, improving adherence among subjects meeting existing eligibility criteria. 


\section{Methods}

\section{Review of literature on levels of adherence to statin medication}

We identified studies using the key words statins, adherence, compliance and concordance, searching Pub-Med. We included only large well conducted randomised control trials of statins for the primary and secondary prevention of CVD and studies whose primary aim was to measure adherence with statins for the primary or secondary prevention of CVD in the community setting. We included RCTs which were frequently cited by other studies as providing evidence of statin effectiveness and were adequately randomised and controlled, and provided analysis by intention to treat. Only studies of adherence in the community setting with a clear study design were included.We initially sought to include only studies which used a common operational definition of adherence although this criterion was relaxed in order to increase the number of studies included. No restrictions were placed on the year of the study or the duration of follow up used by the study authors.

Adherence observed within randomised control trials of statin use are shown in table 1. Studies of adherence in the community setting are shown in table 2. 
Table 1: Adherence observed during principal RCT of statins for primary and secondary prevention of cardiovascular disease

\begin{tabular}{|c|c|c|c|c|c|c|c|c|}
\hline Trial & Author, year & $\begin{array}{l}\text { Definition of } \\
\text { adherence }\end{array}$ & Ascertainment & $\begin{array}{l}\text { Mean lowering of } \\
\text { serum cholesterol } \\
\text { concentration }\end{array}$ & $\begin{array}{l}\text { Primary or secondary } \\
\text { prevention }\end{array}$ & Mean age & $\begin{array}{l}\text { Observation } \\
\text { period }\end{array}$ & $\begin{array}{l}\text { Adherence at } \\
\text { end of period }\end{array}$ \\
\hline $\begin{array}{l}\text { AFCAPS/ texCAPS } \\
{[10]}\end{array}$ & JAMA, 1998 & $\geq 75 \%$ & Pill-counts & $19 \%$ & Primary prevention & 58 & 5.2 years & $99 \%$ \\
\hline EXCEL [11] & $\begin{array}{l}\text { Shear et al, } \\
1992\end{array}$ & $\begin{array}{l}\geq 75 \% \text { medication } \\
\text { taken }\end{array}$ & Self report & Not stated & Secondary prevention & 54 & 4 years & $99 \%$ \\
\hline CARE [12] & $\begin{array}{l}\text { Sacks et al, } \\
1996\end{array}$ & $\begin{array}{l}\text { Continuation of } \\
\text { therapy }\end{array}$ & Not-stated & $20 \%$ & Secondary prevention & 59 & Median 5 years & $94 \%$ \\
\hline $4-S$ [13] & $\begin{array}{l}\text { Conroy et al, } \\
1998\end{array}$ & $\begin{array}{l}\text { Continuation of } \\
\text { therapy }\end{array}$ & Not stated & $26 \%$ & Secondary prevention & 58 & Median 5.4 years & $90 \%$ \\
\hline $\begin{array}{l}\text { Heart Protection } \\
\text { Study }[14]\end{array}$ & $\begin{array}{l}\text { Farmer et al, } \\
2003\end{array}$ & $\begin{array}{l}\geq 80 \% \text { medication } \\
\text { taken }\end{array}$ & Pill-counts & $17 \%$ & Secondary prevention & 64 & Median 5 years & $82 \%$ \\
\hline LIPID [15] & $\begin{array}{l}\text { N Eng J Med, } \\
1998\end{array}$ & $\begin{array}{l}\text { Continuation of } \\
\text { therapy }\end{array}$ & Not-stated & $18 \%$ & Secondary prevention & 62 & 6.1 years & $81 \%$ \\
\hline WOSCOPS [16] & $\begin{array}{l}\text { Shepherd et al, } \\
1995\end{array}$ & $\geq 75 \%$ & Pill-counts & $20 \%$ & Primary prevention & 55 & Mean 4.9 years & $70 \%$ \\
\hline
\end{tabular}


Table 2: Studies of statin adherence in the community setting*

\begin{tabular}{|c|c|c|c|c|c|c|c|}
\hline Authors, year & Study design & $\begin{array}{l}\text { Operational definition of } \\
\text { adherence }\end{array}$ & Method of ascertainment & $\begin{array}{l}\text { Primary or secondary } \\
\text { prevention }\end{array}$ & $\begin{array}{l}\text { Mean } \\
\text { Participant age }\end{array}$ & $\begin{array}{l}\text { Observation } \\
\text { period }\end{array}$ & $\begin{array}{l}\text { Adherence at end } \\
\text { of period }\end{array}$ \\
\hline $\begin{array}{l}\text { Kim A. Eagle et al, } \\
2004 \text { [2] }\end{array}$ & cohort study & Continuation of therapy & $\begin{array}{l}\text { Structured telephone } \\
\text { interview }\end{array}$ & Secondary prevention & 65 & 6 months & $87 \%$ \\
\hline L Wei et al, 2002 [3] & cohort study & $\begin{array}{l}\geq 80 \% \text { medication } \\
\text { availability }\end{array}$ & Pharmacy records & Secondary prevention & 67 & 2.4 years & $64 \%$ \\
\hline $\begin{array}{l}\text { Marie Bouchard et al, } \\
2007 \text { [4] }\end{array}$ & $\begin{array}{l}\text { Nested case control } \\
\text { study }\end{array}$ & $\geq 90 \%$ prescriptions filled & $\begin{array}{l}\text { Data retrieved from health } \\
\text { care database }\end{array}$ & Primary prevention & 63 & 1 year & $62 \%$ \\
\hline $\begin{array}{l}\text { Jean Lachaine et al, } \\
2006 \text { [5] }\end{array}$ & $\begin{array}{l}\text { Retrospective } \\
\text { cohort study }\end{array}$ & $\begin{array}{l}\geq 80 \% \text { medication } \\
\text { availability }\end{array}$ & Pharmacy records & $\begin{array}{l}\text { Primary and secondary } \\
\text { prevention }\end{array}$ & 58 & 2 years & $58 \%$ \\
\hline $\begin{array}{l}\text { Elizabeth Poluzzi et } \\
\text { al, } 2007 \text { [6] }\end{array}$ & $\begin{array}{l}\text { Retrospective } \\
\text { cohort study }\end{array}$ & $\begin{array}{l}\text { 300/365 minimum daily } \\
\text { doses received }\end{array}$ & Health Authority database & $\begin{array}{l}\text { Primary and secondary } \\
\text { prevention }\end{array}$ & $\geq 40$ & 3 years & $52 \%$ \\
\hline $\begin{array}{l}\text { David F Blackburn 1, } \\
2005 \text { [7] }\end{array}$ & $\begin{array}{l}\text { Retrospective } \\
\text { cohort study }\end{array}$ & $\geq 80 \%$ prescriptions filled & Pharmacy records & Secondary prevention & 58 & 5 years & $49 \%$ \\
\hline Benner et al 2005 [8] & $\begin{array}{l}\text { Retrospective } \\
\text { cohort study }\end{array}$ & Continuation of therapy & Pharmacy records & $\begin{array}{l}\text { Primary and secondary } \\
\text { prevention }\end{array}$ & 60 & 3 years & $21 \%$ \\
\hline
\end{tabular}

* Studies of those with new and existing prescriptions for Statin medication for primary or secondary prevention outside the clinical trial setting. 
The data summarised in Tables 1 and 2, including the observed declines in adherence with time suggest that an assumed average adherence with medication over 10 years of around $50 \%$ is reasonable.

\section{Simulation of proposed scenarios using cohort study data}

The Melbourne Collaborative Cohort Study was a prospective study of 41141 people (17 049 men), with a mean age of 55 at baseline. (range 25-75) Mean values for systolic blood pressure and total serum cholesterol concentration were $137 \mathrm{mmHg}$ $(\mathrm{SD}=1.05)$ and $5.5 \mathrm{mmol} / \mathrm{l}(\mathrm{SD} 1.05) 3.8 \%$ of cohort participants had diabetes and $11 \%$ were smokers. Recruitment occurred between 1990 and 1994. [17]

This study population was suitable for estimating the benefits of cardiovascular preventive strategies because the data set contained all necessary data on participants that was required to derive a risk score using the Framingham equations, and few subjects had existing CVD.

From the source population, 2485 subjects were excluded due to having existing CVD and a further 388 subjects were excluded due to missing data leaving 38,268 individuals. Data on CVD risk factors for each of these individuals were transferred into an Excel spreadsheet.

We used the equations of Anderson et al [18] (based on the experience of the Framingham cohort) to estimate 10 year risk of CVD onset and death using age, sex, systolic blood pressure, smoking status, diabetes status and total serum cholesterol concentration. The risk equation for calculating 10 year risk of CVD death, written as Excel code is included as a supplementary on line file. 
Having used this method to estimate risk scores for each cohort member we went on to estimate how competing assumptions with respect to statin adherence and the risk threshold used to determine eligibility for therapy would alter the population level benefits from statin therapy. This was achieved by constructing 3 scenarios $-\mathrm{a}$ baseline scenario implementing the current NICE guidelines for statin use, an enhanced compliance scenario and a lowered threshold scenario. Individuals assigned to be adherent with statins were assumed to experience a $20 \%$ reduction in their serum total cholesterol concentration. This was chosen as a representative rounded value consistent with clinical trials data. (see Table 1). Adherence is here defined as taking $\geq 80 \%$ of the prescribed monthly dose of medication. Adherence was assumed to be unrelated to the magnitude of risk among those deemed eligible for therapy.

In the baseline scenario, only subjects exceeding the NICE risk threshold received statins and adherence was hypothetically assumed to be maintained at $50 \%$.

The details of the alternative scenarios we compare with this baseline scenario are:

a) Enhanced adherence scenario. This assumes an instantaneous and sustained increase by $50 \%$ (from $50 \%$ to $75 \%$ ).

b) Lowered prescribing threshold scenario, where the threshold is adjusted downward sufficiently to result in an increase in statin consumption equivalent to that under scenario a). This was achieved at a 10 year risk threshold of approximately $15.5 \%$.

\section{Assignment of adherence}

Adherent individuals were assigned at random using a random number generator within Excel. 
Adherent individuals were assumed to experience an instantaneous and sustained reduction of $20 \%$ in their serum cholesterol concentration and their Framingham risk score was recalculated to reflect this.

Risk in non adherent individuals was a function of their baseline risk factor values. 


\section{Results}

Adherence with statin therapy in clinical trials (Table 1) tends to be much higher than in everyday practice (Table 2). The shorter follow up in the latter studies makes them likely underestimators of the difference in the longer term.

The distribution of 10 year risk of CVD (among those free of CVD at baseline) among members of the source study population are shown in Supplementary Figure 1. The distribution is positively skewed.

\section{[Supplementary Figure 1 about here]}

Supplementary Figure 1: Distribution of 10 year of CVD within simulation cohort; risk scores estimated using Framingham equations provided by Anderson et al ${ }^{18}$ for 38,264 individuals without existing CVD*

Predicted outcomes over 10 years under the three scenarios are given in Table 3. 


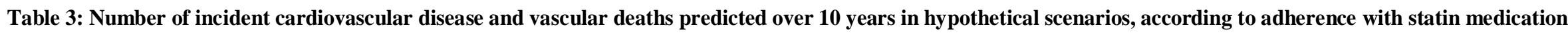
and the treatment threshold for prescribing. Estimates derived using risk prediction equations based on Framingham data and provided by Anderson et al. [18]

\begin{tabular}{|c|c|c|c|c|}
\hline $\begin{array}{l}\mathrm{N}=38,264 \\
\text { (Those among cohort of } 41,141 \text { with no existing } \\
\text { CVD) }\end{array}$ & Untreated & $\begin{array}{l}\text { Baseline scenario } \\
\text { Adherence }=\mathbf{5 0 \%} *^{\dagger}\end{array}$ & $\begin{array}{l}\text { Enhanced adherence } \\
\text { counterfactual scenario } \\
\text { Adherence }=75 \% *^{\dagger}\end{array}$ & $\begin{array}{l}\text { Lowered prescribing } \\
\text { threshold counterfactual } \\
\text { scenario Adherence }=50 \%\end{array}$ \\
\hline Number adherent to statin therapy & 0 & $\begin{array}{c}4563 \\
\text { (11.9\% of population) }\end{array}$ & $\begin{array}{c}6971 \\
\text { (18.2\% of population) }\end{array}$ & $\begin{array}{c}6991^{\S} \\
(18.3 \% \text { of population })\end{array}$ \\
\hline Predicted incident cardiovascular disease over 10 years & $\begin{array}{c}5390(13.1 \% \text { of source } \\
\text { population })\end{array}$ & $\begin{array}{c}5215(13.6 \% \text { of source } \\
\text { population })\end{array}$ & $\begin{array}{c}5124(13.4 \% \text { of source } \\
\text { population })\end{array}$ & $\begin{array}{l}5145(13.5 \% \text { of source } \\
\text { population })\end{array}$ \\
\hline $\begin{array}{l}\text { Additional incident cardiovascular disease averted } \\
\text { (above baseline) }\end{array}$ & - & - & 91 & 70 \\
\hline Predicted cardiovascular deaths over 10 years & 710 & 640 & 603 & 622 \\
\hline Cardiovascular deaths averted & - & 70 & 107 & 88 \\
\hline $\begin{array}{l}\text { Additional cardiovascular deaths averted (above } \\
\text { baseline) }\end{array}$ & - & - & $\begin{array}{c}37 \\
\text { (53\% improvement from } \\
\text { baseline) }\end{array}$ & $\begin{array}{c}18 \\
\text { (25\% improvement from } \\
\text { baseline) }\end{array}$ \\
\hline
\end{tabular}


* Adherence assumed to be unrelated to absolute risk among those eligible for statins

$\dagger$ Eligible for treatment if 10 year risk $\geq 20 \%$

$\ddagger$ Eligible if 10 year risk $\geq 15.5 \%$

$\S$ The number of adherent individuals could not be made exactly equal due to stochastic nature of simulation. 
In the baseline scenario, among those without existing CVD and not assigned to statins, 5390 onsets of CVD and 710 CVD deaths would be expected over 10 years. Twenty-four percent $(9,279 / 38,268)$ of the source population had an estimated 10 year risk of $C V D \geq 20 \%$, and were eligible for therapy under the NICE guidelines. Fifty percent (4563) of these are assigned to be adherent to statin therapy and among them, an estimated 174 CVD onsets and 70 CVD deaths were averted.

In the lowered treatment threshold scenario, 6991 were assigned to be adherent resulting in an estimated additional 70 CVD onsets and 18 CVD deaths being averted. In the enhanced adherence scenario, 6971 individuals were assigned to be adherent to statin medication, resulting in an additional 91 CVD onsets and 37 CVD deaths being averted.

The enhanced adherence scenario, in comparison with the lowered threshold scenario, shows a modest gain in averting CVD onsets but a, proportionally, much larger gain in averting CVD deaths - roughly, a doubling. This implies that the incremental cost effectiveness would also be approximately double.

\section{Sensitivity analyses}

We examined how robust our results were to the specified increase in adherence, the proposed reduction in cholesterol from using statins and the assumed baseline level of adherence. We found the relative benefit of the increased adherence scenario remained largely unchanged for plausible alternative values of these variables. 
Table 4: Sensitivity analyses with alternative assumptions regarding adherence and cholesterol lowering

\begin{tabular}{|c|c|}
\hline $\begin{array}{c}\text { Deaths averted in } \\
\text { enhanced adherence } \\
\text { scenario }\end{array}$ & $\begin{array}{l}\text { Deaths averted in } \\
\text { lowered treatment } \\
\text { threshold scenario }\end{array}$ \\
\hline
\end{tabular}

Reduction in total serum cholesterol concentration achieved with statin therapy

$\begin{array}{rrr}10 \% & 18 & 9 \\ 30 \% & 54 & 25 \\ 40 \% & 68 & 33\end{array}$

Level of adherence at baseline

$\begin{array}{lll}40 \% & 28 & 14 \\ 60 \% & 43 & 21\end{array}$

Increase in adherence proposed 


\section{Discussion}

Relative to a baseline based on current NICE guidance, twice as many CVD deaths would be prevented by a $50 \%$ improvement in adherence (from 50 to $75 \%$ ) under current prescribing guidelines, than by relaxing those guidelines to an extent that would result in a similar increase in statin consumption.

It is not surprising that a strategy that concentrates on enhancing treatment among high risk individuals yields bigger benefits than a strategy of extending prescribing to lower risk individuals. However, the magnitude of the difference is notable and it serves to emphasise the need to find more effective means to increase adherence especially over the long term

Although we have not estimated cost effectiveness of any particular strategy, our results indicate that if adherence could be improved by the magnitude specified here at a cost not greater than that of extended prescribing it should be more cost effective. This excludes actual medication costs, and reduced waste associated with improved adherence should further improve the cost effectiveness profile of this strategy.

Recent Cochrane reviews conducted in this area suggest that measures such as telephone reminders, self-monitoring mechanisms, and improved patient information may increase short term adherence but the long term effectiveness of such measures is unknown.[19,20]

Our estimates of absolute benefit should be viewed cautiously given the simplifying assumptions employed. We have made no attempt to account for poly-pharmacy or for the fact that in practice many individuals above risk thresholds would remain unidentified. 
The Framingham equations, used here, have been criticised for overestimating CVD risk, and so overestimate numbers eligible for therapy [21]. Nevertheless they are recommended by NICE.[22] Although they may overestimate absolute risk, the effects of this on our estimates of relative benefit should be more modest. While some studies have suggested that Framingham overestimates risk by proportionally similar amounts across risk strata [23] others have suggested that the overestimation of risk was greatest in lower risk populations. [24] Were Framingham to overestimate risk more among low risk strata of the cohort used here, then this may lead to an overestimation of benefit from the wider prescribing scenario, in which a greater number at lower risk are treated.

We have used a Southern hemisphere cohort with a low prevalence of smoking; absolute benefits of cholesterol lowering should be higher in higher risk populations with higher smoking prevalence. Mean systolic blood pressures and serum cholesterol concentrations are similar to the values for 45 to 64 year olds in the 2003 Health Survey for England. [25]

The relatively modest benefit of the 2 strategies in absolute terms is a result of their application to a relatively low risk population for the purposes of primary prevention.

We have assumed that adherence is unrelated to risk. However, even with a placebo, poor adherence appears to be associated with increased risk of death, [26] along with higher age, low mood, [27] low socioeconomic status, [28] smoking, [29] hypertension and number of concurrent medications [8] If risk among the nonadherent is higher than among the adherent, our estimates of the relative benefit from enhanced adherence will be underestimates.

Although many CVD risk factors follow an approximately normal distribution, overall CVD risk is positively skewed (see figure 1). This is a consequence of the 
multiplicative way in which CVD risk factors combine to determine overall risk. Our finding, that potential gains are greater when efforts are concentrated on the top tail of the distribution of overall risk, is not incompatible with Rose's observations that strategies which focus on the top tails of risk factor distributions, considered one at a time, fail to identify most of those with high overall risk. [30]

\section{Conclusions}

Failure to take account of adherence levels that are typically achieved in practice can lead to an overestimation of the potential benefits from chemopreventive strategies. It may also inadvertently result in policies for the use of statins that fail to maximise benefits from their use.

More work is needed on the best ways to enhance long term adherence.

\section{Implications for policy and practice}

- Long term adherence to statin medication is likely to be around $50 \%$.

- Improving adherence among the highest risk individuals will avert substantially more CVD deaths than would equivalent increases in prescribing directed at those at lower risk.

- Effective interventions to improve long term adherence with medication are urgently needed. 
Acknowledgements: Material upon which article is based was presented orally at the October 2007 EUPHA conference, Helsinki.

Exclusive licence: The Corresponding Author has the right to grant on behalf of all authors and does grant on behalf of all authors, an exclusive licence (or non-exclusive for government employees) on a worldwide basis to the BMJ Publishing Group Ltd and its Licensees to permit this article (if accepted) to be published in Journal of Epidemiology and Community Health and any other BMJPGL products to exploit all subsidiary rights, as set out in our licence

Ethical approval: not required

Conflict of interest statement: The authors declare that there are no competing interests. 


\section{Reference List}

1. Law MR, Wald NJ, Rudnicka AR. Quantifying effect of statins on low density lipoprotein cholesterol, ischaemic heart disease, and stroke: systematic review and meta-analysis. BMJ. 2003;326(7404):1407-8.

2. Eagle KA, Kline-Rogers E, Goodman SG et al. Adherence to evidence-based therapies after discharge for acute coronary syndromes: an ongoing prospective, observational study. Am.J.Med. 2004;117(2):73-81.

3. Wei L, Wang J, Thompson P, Wong S, Struthers AD, MacDonald TM. Adherence to statin treatment and readmission of patients after myocardial infarction: a six year follow up study. Heart. 2002;88(3):229-33.

4. Bouchard MH, Dragomir A, Blais L, Berard A, Pilon D, Perreault S. Impact of adherence to statins on coronary artery disease in primary prevention. Br.J.Clin.Pharmacol. 2007.

5. Lachaine J, Rinfret S, Merikle EP, Tarride JE. Persistence and adherence to cholesterol lowering agents: evidence from Regie de l'Assurance Maladie du Quebec data. Am.Heart J. 2006;152(1):164-69.

6. Poluzzi E, Strahinja P, Vaccheri A et al. Adherence to chronic cardiovascular therapies: persistence over the years and dose coverage. Br.J.Clin.Pharmacol. 2007;63(3):346-55. 
7. Blackburn DF, Dobson RT, Blackburn JL, Wilson TW, Stang MR, Semchuk WM. Adherence to statins, beta-blockers and angiotensin-converting enzyme inhibitors following a first cardiovascular event: a retrospective cohort study. Can.J.Cardiol. 2005;21(6):485-88.

8. Benner JS, Pollack MF, Smith TW, Bullano MF, Willey VJ, Williams SA. Association between short-term effectiveness of statins and long-term adherence to lipid-lowering therapy. Am.J.Health Syst.Pharm. 2005;62(14):1468-75.

9. Modification of Cardiovascular risk assessment and the modification of blood lipids for the primary and secondary prevention of cardiovascular disease. www.nice.org.uk/CG067 NICE clinical guideline 67. 8.

10. Downs JR, Clearfield M, Weis S et al. Primary prevention of acute coronary events with lovastatin in men and women with average cholesterol levels: results of AFCAPS/TexCAPS. Air Force/Texas Coronary Atherosclerosis Prevention Study. JAMA. 1998;279(20):1615-22.

11. Shear CL, Franklin FA, Stinnett S et al. Expanded Clinical Evaluation of Lovastatin (EXCEL) study results. Effect of patient characteristics on lovastatininduced changes in plasma concentrations of lipids and lipoproteins. Circulation. 1992;85(4):1293-303.

12. Sacks FM, Pfeffer MA, Moye LA et al. The effect of pravastatin on coronary events after myocardial infarction in patients with average cholesterol levels. 
Cholesterol and Recurrent Events Trial investigators. N.Engl.J.Med. 1996;335(14):1001-9.

13. The 4-S Study Group. Randomised trial of cholesterol lowering in 4444 patients with coronary heart disease: the Scandinavian Simvastatin Survival Study (4S). Lancet. 1994;344(8934):1383-89.

14. Farmer JA, Gotto AM, Jr. The Heart Protection Study: expanding the boundaries for high-risk coronary disease prevention. Am.J.Cardiol. 2003;92(1A):3i-9i.

15. Prevention of cardiovascular events and death with pravastatin in patients with coronary heart disease and a broad range of initial cholesterol levels. The LongTerm Intervention with Pravastatin in Ischaemic Disease (LIPID) Study Group. N.Engl.J.Med. 1998;339(19):1349-57.

16. Shepherd J, Cobbe SM, Ford I et al. Prevention of coronary heart disease with pravastatin in men with hypercholesterolemia. West of Scotland Coronary Prevention Study Group. N.Engl.J.Med. 1995;333(20):1301-7.

17. Giles GG, English DR. The Melbourne Collaborative Cohort Study. In E Riboli and R Lambert (eds). Nutrition and lifestyle: opportunities for cancer prevention. IARC Scientific Publications No 156. Lyon; International Agency for Research on Cancer, 2002; 69-70.

18. Anderson KM, Odell PM, Wilson PW, Kannel WB. Cardiovascular disease risk profiles. Am Heart J. 1991 Jan;121(1 Pt 2):293-8. 
19. Haynes RB, Ackloo E, Sahota N, McDonald HP, Yao X. Interventions for enhancing medication adherence. Cochrane Database of Systematic Reviews 2008, Issue 2. Art. No. CD000011. DOI: 10.1002/14651858.CD000011.pub3.

20. Schedlbauer A, Schroeder K, Peters TJ, Fahey T. Interventions to improve adherence to lipid lowering medication. Cochrane Database of Systematic Reviews 2004, Issue 4. Art. No.: CD004371. DOI:

10.1002/14651858.CD004371.pub2

21. Neuhauser HK, Ellert U, Kurth BM. A comparison of Framingham and SCORE-based cardiovascular risk estimates in participants of the German National Health Interview and Examination Survey 1998. Eur J Cardiovasc Prev Rehabil. 2005 Oct;12(5):442-50.

22. National institute for clinical excellence. Statins for the prevention of cardiovascular events in patients at increased risk of developing cardiovascular disease or those with established cardiovascular disease. http://www.nice.org.uk/guidance/TA94 . 1007.

23. Brindle $\mathrm{P}$ et al. Predictive accuracy of the Framingham coronary risk score in British men: prospective cohort study. BMJ. 2003 Nov 29;327(7426):1238-9.

24. Menotti A, Puddu PE, Lanti M. Comparison of the Framingham risk functionbased coronary chart with risk function from an Italian population study. Eur Heart J. 2000 Mar;21(5):365-70. 
25. National Centre for Social Research. Health survey for England 2003. Decemebr 2004 Department of Health publications. www.dh.gov.uk/en/Publicationsandstatistics/Publications/PublicationsStatistics/ DH_4098712.

26. Simpson SH, Eurich DT, Majumdar SR, Padwal RS, Tsuyuki RT, Varney J, Johnson JA.A meta-analysis of the association between adherence to drug therapy and mortality. BMJ. 2006 Jul 1;333(7557):15

27. Kulkarni SP, Alexander KP, Lytle B, Heiss G, Peterson ED. Long-term adherence with cardiovascular drug regimens. Am.Heart J. 2006;151(1):185-91.

28. Kopjar B, Sales AE, Pineros SL, Sun H, Li YF, Hedeen AN. Adherence with statin therapy in secondary prevention of coronary heart disease in veterans administration male population. Am.J.Cardiol. 2003;92(9):1106-8.

29. Horwitz RI, Viscoli CM, Berkman L et al. Treatment adherence and risk of death after a myocardial infarction. Lancet. 1990;336(8714):542-45.

30. Rose, G. Sick Individuals and Sick Populations Int.J.Epiodemiol. 1985, 14:3238. 